\title{
Plant communities as bioclimate indicators on Isla Navarino, one of the southernmost forested areas of the world
}

\section{Las comunidades vegetales como indicadores bioclimáticos en isla Navarino, una de las áreas forestales más australes del planeta}

\author{
José Antonio Molina ${ }^{1 *}$, Ana lumbreras ${ }^{1}$, Alberto Benavent-González ${ }^{1}$, Ricardo RozzI ${ }^{2,3,4}$ \& \\ LEOPOLDO G. SANCHO ${ }^{1}$
}

1Departamento de Biología Vegetal II, Universidad Complutense de Madrid, Spain. ${ }^{2}$ Parque Etnobotánico Omora, Sede Puerto Williams, Universidad de Magallanes, Chile. ${ }^{3}$ Instituto de Ecología y Biodiversidad (IEB), Santiago, Chile. ${ }^{4}$ Department of Philosophy and Religion Studies, University of North Texas, USA. *jmabril@ucm.es

\begin{abstract}
Variation in climactic vegetation with altitude is widely used as an ecological indicator to identify bioclimatic belts. Tierra del Fuego is known to undergo structural and functional changes in forests along altitudinal gradients. However there is still little knowledge of the changes in plant-community composition and plant diversity -including both forests and tundra and their area of contact (krummholz) - and their relation to climatic factors along an altitudinal gradient. This study focuses on Isla Navarino (Chile), at the eastern part of Beagle Channel, included in the Cape Horn Biosphere Reserve. Numerical analysis revealed four community types along the cited gradient: a) mixed forest of Nothofagus betuloides and Nothofagus pumilio distributed at lower altitudes (0-300 masl); b) pure forests of Nothofagus pumilio distributed at higher altitudes (350-550 masl); c) krummholz forest of Nothofagus pumilio near the tree line (500-550 masl); and d) pulvinate-cushion vegetation -tundra- of Bolax gummifera and Abrotanella emarginata at altitudes above 600 masl. Species turnover showed that the most abrupt change in plant composition occurs from 550 to 600 masl, producing a drastic landscape change when the high-altitude tree limit formed by dwarf forest of deciduous $N$. pumilio yields to tundra at a calculated biotemperature of $2.9^{\circ} \mathrm{C}$. Two other minor changes occur in the understory of pure Nothofagus pumilio forests: a transition from a thermophilous element to a more orophilous element at a calculated biotemperature of $4.3{ }^{\circ} \mathrm{C}$, and a drop in the number of species as the erect forest changes to low krummholz forest at a calculated biotemperature of 3.3 ${ }^{\circ} \mathrm{C}$. The identification of bioclimatic belts based on changes in vegetation and the calculation of biotemperature along the altitudinal gradient suggests that the following plant communities are reliable regional bioclimatic bioindicators: lowermiddle-oroantiboreal mixed forest of Nothofagus betuloides-Nothofagus pumilio; oroantiboreal pure forest of Nothofagus pumilio; hemi oroantarctic krummholz of Nothofagus pumilio; and oroantartic tundra of Bolax gummifera and Abrotanella emarginata.
\end{abstract}

KEYwords: Altitudinal gradient, bioclimatic zones, Cape Horn Biosphere Reserve, species diversity, Sub-Antarctic habitats.

\section{RESUMEN}

La variación de la vegetación climática con la altitud es ampliamente utilizada como indicador ecológico para identificar pisos bioclimáticos. En bosques de Tierra del Fuego se han estudiado los cambios estructurales y funcionales a lo largo de gradientes altitudinales. Sin embargo, poco se conoce sobre la composición de las comunidades vegetales, su diversidad y su relación con factores climáticos en gradientes altitudinales que incluyan bosques, tundra y su área de contacto ( $k$ rummholz). Este estudio se centró en la Isla Navarino (Chile), situada en la parte oriental del canal de Beagle, incluida en la Reserva de la Biosfera Cabo de Hornos. El análisis numérico determinó cuatro comunidades vegetales tipo a lo largo del gradiente de estudio: a) bosques mixtos de Nothofagus betuloides y Nothofagus pumilio, localizados en las zonas bajas (0-300 m s.n.m.); b) bosques puros de Nothofagus pumilio, ubicados en altitudes medias (350-550 m s.n.m); c) krummholz de Nothofagus pumilio en el límite altitudinal del bosque (500-550 m s.n.m.); y d) matorrales bajos en cojín -tundra- de Bolax gummifera y Abrotanella emarginata, ubicadas a altitudes por encima de los $600 \mathrm{~m}$. El mayor recambio de especies se produjo entre los 550 y 600 metros de altitud, a una biotemperatura calculada de $2,9^{\circ} \mathrm{C}$, con un drástico cambio en el paisaje en el que el krummholz de Nothofagus pumilio da paso a la tundra. Dentro de la banda forestal, se observaron dos recambios menores en la composición florística del sotobosque. Uno, entre los 300-350 m s.n.m, a una biotemperatura de $4,3{ }^{\circ} \mathrm{C}$, donde hay 
un recambio entre el elemento más termófilo y el más orófilo. Y otro, entre los 400-500 m s.n.m, a una biotemperatura de $3,3{ }^{\circ} \mathrm{C}$, basado en un descenso en el número de especies cuando el bosque da paso al krummholz. La sectorización bioclimática basada en los cambios en la vegetación y el cálculo de la biotemperatura a lo largo del gradiente altitudinal revela las siguientes comunidades vegetales como bioindicadores bioclimáticos fiables para la región de estudio: bosques mistos del piso inferior-medio antiboreal de Nothofagus betuloides y Nothofagus pumilio; bosques supra-oroantiboreales puros de Nothofagus pumilio; krummholz oroantárctico de Nothofagus pumilio; y tundra oroantártica de Bolax gummifera y Abrotanella emarginata.

Palabras clave: Gradiente altitudinal, zonas bioclimáticas, Reserva de la Biosfera Cabo de Hornos, diversidad de especies, hábitats subantárticos.

\section{INTRODUCTION}

Cape Horn Biosphere Reserve (CHBR) is located at the southern tip of South America (Tierra de Fuego Archipelago) -Fig.1- and hosts the southernmost forests on Earth (Rozzi et al. 2006a). This biosphere reserve is included in one of the 24 wilderness areas remaining on the planet (Mittermeier et al. 2003), and one of the less impacted by human activities (human footprint) on Earth (Sanderson et al. 2002). It is also considered an outstanding biodiversity hotspot in South America, with high endemicity rate (above 50\%) among its non-vascular flora (bryophytes), finding many species their northern distribution limit in the archipelago region, around $41.5^{\circ} \mathrm{S}$ (Rozzi et al. 2008). For its unique biodiversity, as well as cultural diversity and historical significance, UNESCO approved the creation of CHBR in 2005 (Rozzi et al. 2006b).

Tierra del Fuego includes an extensive archipelago between latitudes $52^{\circ}$ and $56^{\circ} \mathrm{S}$, separated from South American continent by the Strait of Magellan. Isla Navarino $\left(55^{\circ} \mathrm{S}\right)$ is south of Isla Grande Tierra del Fuego, from which is separated by the Beagle Channel. The archipelago is surrounded by oceans in three directions (E, S, and W), determining the strong oceanity that dominates the climate of the area, and is strongly exposed to permanent westerly winds. These west winds are a continuous stress factor for plant life throughout the area, and lead to foliage or bud damage, lower net photosynthesis and lower soil-surface temperature (Webb \& Harwood 1993, Lara et al. 2005). In addition, the geomorphology of the area is determined by the presence of the mountainous reliefs of the Southern Andes, a range aligned N-S or NW-SE which produces abrupt changes in climate over short distances and is responsible for the strong longitudinal precipitation gradient in the area. The constant humid winds throughout the year produce high rainfall at the windward side of the mountains, decreasing from approximately $4000 \mathrm{~mm}$ at west coast to $200 \mathrm{~mm}$ at east parts (Hoffmann 1975, Tuhkanen 1992, Santana 2006). Despite the marked rainfall gradient, marked continental influences are absent and a very oceanic climate dominates the area (Tuhkanen 1992, Rozzi et al. 2012). The regional bioclimate is anti-boreal hyperoceanic, characterised by low values in the continentality index $(\mathrm{Ic}=7.2)$ and ombrothermic index ( $\left.\mathrm{Io}_{0}=6.2\right)$-Luebert \& Pliscoff 2006-. These environmental conditions drive plant ecology and plant community distribution in this region (Cuevas 2000).

The main vegetation matrix in the Magellanic Region consists of deciduous and perennial Magellanic forests, Magellanic tundra, and Patagonian steppe (Pisano 1981). The climactic vegetation in this region, sensu Font-Quer (2001), is widely distributed. The forests of the CHBR have been ascribed to the Magellanic rainforests (Veblen et al. 1996), boreal-austromagellanic forests (Amigo \& Rodríguez-Guitián 2001), temperate-antiboreal forests (Luebert \& Pliscoff 2006) or Magellanic subantarctic forests (Rozzi et al. 2012). They are dominated by three broad-leaf species of the genus Nothofagus: Nothofagus antarctica (G.Forst.) Oerst., N. betuloides (Mirb.) Oerst. and N. pumilio (Poepp. \& Endl.) Krasser. Distribution of Nothofagus forests has been related to climate, soil, and topographic factors (Frangi \& Richter 1994, Gutiérrez et al. 1991, Veblen et al. 1996, Donoso 1995, Gerding \& Thiers 2002). In CHBR, the distribution of Nothofagus forests is conditioned in both horizontal and vertical directions. The precipitation gradient from west to east, the high oceanity, and the drainage capacity of the substrate confine Nothofagus forests to a central band oriented NW to SE. The high precipitation in the west coast plus the deficient drainage of the substrate (metamorphic and plutonic materials) prevents Nothofagus species (mainly $N$. pumilio) from growing in waterlogged zones. Furthermore, the aridity produced by rain shadow excludes Nothofagus species from the eastern steppe. The distribution of Nothofagus is also conditioned in altitude. The timber line, one of the most characteristic features of the landscape, is particularly low in this part of the world, and has its regional higher limit at 450-650 masl on Isla Grande Tierra del Fuego and Isla Navarino (Rozzi et al. 2006a), becoming lower towards the south and west, where the superoceanic moorland communities evolve into Magellanic tundra (Tuhkanen 1992). This low timberline altitude is determined by oceanity, wind exposure and biotemperature, which all limit the growth of Nothofagus species (Lara et al. 2005, Fajardo et al. 2011). The tundra of Tierra del Fuego consists of a complex of scrub and bog vegetation 
characterized by cushion plants, prostrate dwarf shrubs, graminoid plants, lichens, and bryophytes. The distribution of this plant complex is associated with extreme conditions, and determined by the nature of the substrate and water availability (Pisano 1983). In addition, Patagonian steppe consists mainly of graminoid vegetation of Festuca gracillima Hook.f. It is restricted to the drier and warmer areas of Tierra del Fuego, mainly located in the NE part of Isla Grande de Tierra del Fuego (Pisano 1977).

Vascular plants and vegetation have been widely used as ecological indicators in altitudinal gradients (Zonneveld 1983, Kesler 2000), and has led to the identification of bioclimatic belts in Arctic zones (Sieg \& Daniëls 2005). Although studies on structural and functional changes in forests along altitudinal gradients have been conducted in Tierra del Fuego (Barrera et al.2000, Frangi et al. 2005), this is the first work studying changes in floristic composition and diversity along an altitudinal gradient, including both forests and tundra and their area of contact (krummholz). This study focuses on Isla Navarino (Chile), at the eastern part of Beagle Channel (Fig. 1), where old-growth forests are still well preserved. The research objectives were: (a) to identify the climactic plant community types along an altitudinal gradient, (b) to relate vegetation transitions and biodiversity to bioclimates, and (c) to identify bioclimatic belts. The identification of plant community types as bioindicators can be useful in detecting or even predicting bioclimatic tendencies.

\section{METHODS}

\section{STUdy SITE}

The study site was located in the north central part of Isla Navarino (54 $\left.55^{\circ}-55^{\circ} 20^{\prime} \mathrm{S} ; 67^{\circ} 05^{\prime}-68^{\circ} 22^{\prime} \mathrm{W}\right)$, establishing an altitudinal gradient from sea level up to 800 masl along Cerro Bandera Hill (Fig. 1). The island is on the southern side of the eastern part of Beagle Channel, covering nearly $2500 \mathrm{~km}^{2}$ of rugged terrain. From a morphostructural viewpoint, most of the area forms part of the Tierra del Fuego ranges composed of highly altered Paleozoics rocks, Jurassic metamorphic rocks and Cretaceous turbidites, all of which display plutonic intrusions (Olivero \& Martinioni 2001, Menichetti et al. 2008). Isla Navarino is characterized by a marked oceanic climate with cool summers (mean temperature from 8 to $11{ }^{\circ} \mathrm{C}$ ) and mild winters (mean temperature from -2 to $4{ }^{\circ} \mathrm{C}$ ) despite its proximity to the Antarctica (Tuhkanen 1992). Mean annual temperature is $5.9{ }^{\circ} \mathrm{C}$ at sea level (Rivas-Martínez \& Rivas-Sáenz 19962009) and $0.2{ }^{\circ} \mathrm{C}$ at 800 masl (LG Sancho, unpublished

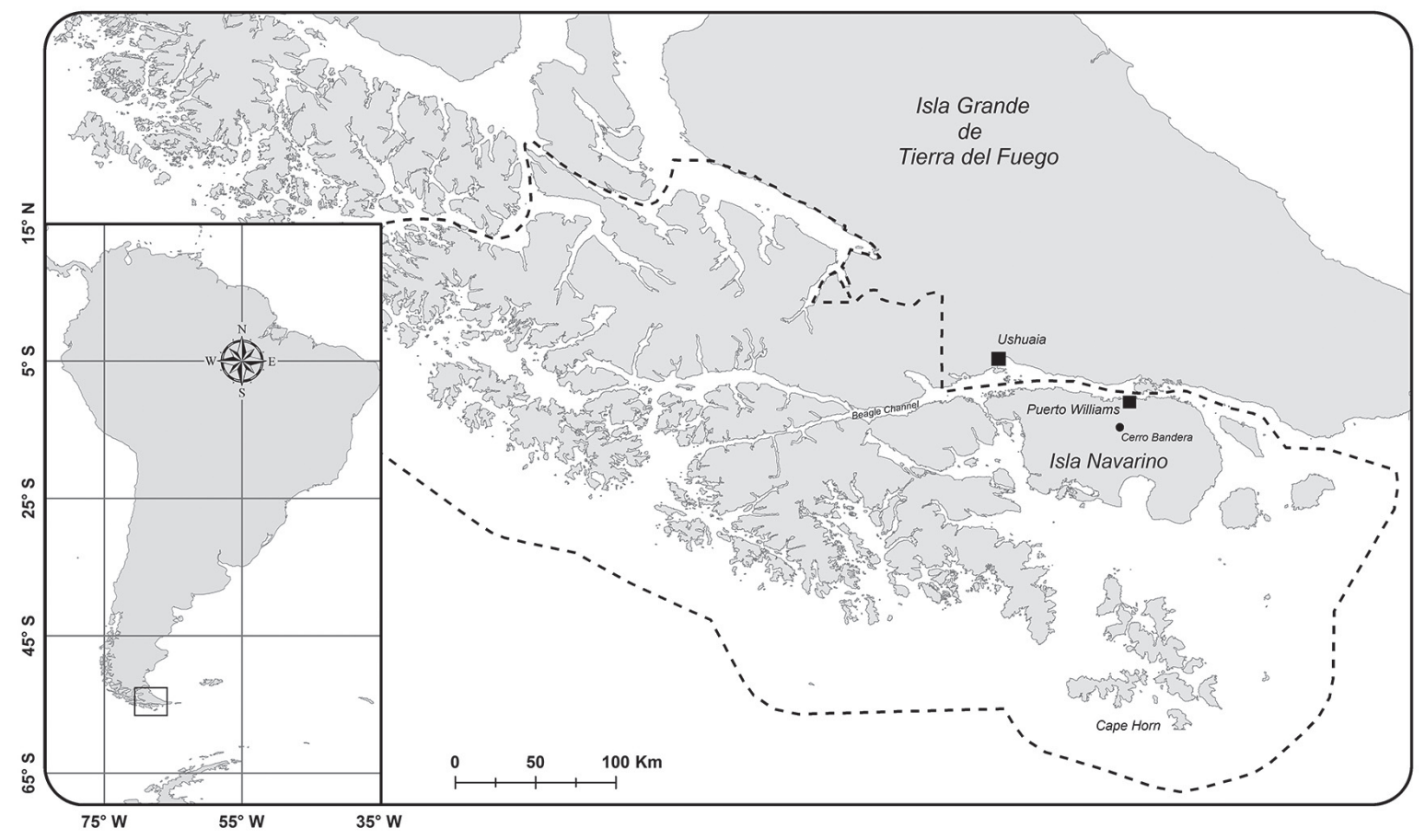

Figure 1. Location of the study area in the Tierra del Fuego Archipelago (Chile). Hash line delimits the area of the Cape Horn Biosphere Reserve.

Figura 1. Localización de la zona de estudio en el Archipiélago de Tierra del Fuego (Chile). La línea segmentada delimita el área de la Reserva de la Biosfera Cabo de Hornos. 
data). Isla Navarino also shows one of the driest climates (449 $\mathrm{mm} /$ year) in the area of the Beagle Channel. The island vegetation is diverse and includes many of the units attributed to the Magellanic Region with the exception of the steppe (Pisano 1977, Moore 1983) -Fig. 2-. Forests cover up to one third of the island $\left(800 \mathrm{~km}^{2}\right)$, and are dominated by deciduous Nothofagus pumilio (eventually, Nothofagus antarctica) and the evergreen Nothofagus betuloides. Other tree species such as the evergreens Drimys winteri J.R.Forst. \& G.Forst and Maytenus magellanica (Lam.) Hook. f. are present (Jax 2010). Forest distribution throughout the island is conditioned by both climatic factors and the presence of peat bogs and wetlands which dominate the island's landscape, along with alpine tundra. In areas where the climatic altitudinal forest limit is not prevented by peat bogs, trees cover the slopes up to about 550-650 masl (Pisano 1977). Above this height, the landscape is dominated by Magellanic tundra (Rozzi et al. 2006a).

\section{FIELDWORK}

Vegetation was sampled in January 2008 along an altitudinal gradient from 0 to 800 masl. We used a systematic sampling method (Kent \& Coker 1992) for vascular plants, which consisted of establishing sample plots at fixed intervals of $50 \mathrm{~m}$ altitude along one transect, gathering a total of 17 plots. Transect location was conditioned by the accessibility of the area, we thus followed a hiking route up to Cerro Bandera, which goes through pristine undisturbed forest up to subalpine tundra. The study area was free of peat bogs, which allows the forest to reach its altitudinal level by constituting an old and developed krummholz formation.

At each point, sampling was performed $50 \mathrm{~m}$ away from the path to avoid human disturbance. The sample quadrat area was $600 \mathrm{~m}^{2}$. It was determined at the medium forest altitude (300 masl) by the minimum area method (BraunBlanquet 1979). We assume the minimum area in tundra is included in $600 \mathrm{~m}^{2}$. Floristic data were recorded for each quadrat, and the cover of each species was estimated using the Braun-Blanquet (1979) scale. The nomenclature of plant species follows The Plant List (http://www.theplantlist. org/). Although our work is based on one transect, we highlight the importance of this work because it is the first fine study of vegetation change along an altitudinal gradient in the region, and contributes to knowledge of vegetation as bioindicators.

\section{NumERICAL ANALYSIS}

The floristic data for the 17 sample plots were transferred to a single table. To reduce the influence of rare species, only species found at two or more sites were included in the analysis. Twinspan (Hill 1979) software was used to produce a divisive clustering classification. The resulting clustering groups were ascribed to plant community types. Twinspan is a robust technique that uses differential species and species with clear ecological preferences, to characterize and separate the classes. This technique assumes the existence of a single, strong dominant gradient (Legendre \& Birks 2012), considered for data set of this study.

Floristic changes in vegetation were related to diversity indices. Species richness (alpha diversity) was observed in each sample plot. Cody's Beta diversity was used as a measure of species turnover along the altitudinal gradient. It was calculated as follows: $\beta \mathrm{c}=(\mathrm{g}(\mathrm{H})+1(\mathrm{H})) 2$, where $\mathrm{g}(\mathrm{H})$ $=$ the number of species gained along the habitat transect and $1(\mathrm{H})=$ the number of species lost over the same transect (Magurran 1988). Previous works have successfully used Cody's Beta diversity along altitudinal gradients (Campoamor \& Molina 2001). We assumed a continuous presence of each taxon between its occurrence at the lowest and highest site where it was found.

\section{BiOTEMPERATURE CALCULATION}

The concept of biotemperature was created by Holdridge (1967) and is a measure of annual heat accumulation effective for plant growth, equal to the average of positive monthly mean temperatures (between 0 and $30{ }^{\circ} \mathrm{C}$ ) divided by 12 . This concept was applied to Tierra del Fuego by Tuhkanen (1992) to characterize the climaticphytogeographical regions in the area. In order to relate vegetation transitions to climate, we calculated the mean monthly temperature at each sample plot along the transect. Temperature data were obtained from the Navarino weather station (Rivas-Martínez \& Rivas-Sáenz 1996-2009). We assumed a mean negative variation of $0.55^{\circ} \mathrm{C}$ for each 100 $\mathrm{m}$ in elevation (Iturraspe et al. 1989, Tuhkanen, 1992), which was determined for the vertical temperature gradient in Ushuaia (Tierra del Fuego, Argentina) located close to Isla Navarino on the north side of Beagle Channel (Fig. 1). We then calculated the biotemperature for each sample site.

\section{RESULTS}

VEGETATION CLASSIFICATION

Two main clusters were identified at the highest cut levels (Fig. 3). Group I corresponds to forests occurring at altitudes from sea level to 550 masl (Fig. 2a-c), and are floristically characterized by plants such as Nothofagus pumilio, Rubus geoides Sm., Gavilea lutea (Comm. ex Pers.) M.N. Correa, Codonorchis lessonii (d'Urv.) Lindl., Blechnum penna-marina (Poir.) Kuhn, Osmorhiza depauperata Phil., and Macrachaenium gracile Hook.f. Group II includes pulvinate-cushion plant communities typical of subantarctic feldmarks, which are distributed from 550 masl to 800 masl (Fig. 2d). Floristically, this tundra vegetation is characterized not only by cushion-like species such as Bolax gummifera (Lam.) Spreng., Abrotanella emarginata (Gaudich.) Cass., Empetrum rubrum Vahl ex Willd., Azorella selago Hook.f., 
and Azorella lycopodioides Gaudich., among others, but also by gramineae such as Luzula alopecurus Desv., and Poa lanuginosa Poir.

Within Group I, two subgroups were identified (Fig. 3). Subgroup Ia corresponds to mixed evergreen and deciduous forest of Nothofagus betuloides and Nothofagus pumilio, distributed at the lower altitudes from sea level to about 300 masl (Fig. 2a). Two characteristic evergreen tree species, Nothofagus betuloides and Drimys winteri, grow in this forest along with the tall shrub Berberis ilicifolia L.f., Drimys winteri is more abundant in the taller forests of the basal horizon (0-100 masl). Low shrubs with high frequency in this mixed forest include: Gaultheria mucronata (L.f.) Hook. \& Arn., and Maytenus disticha (Hook.f.) Urb. Subgroup Ib consists of winter-deciduous pure forest of Nothofagus pumilio distributed in the higher forested belt from about 350 to 550 masl (Fig. 2b). Floristically, this forest is characterized by a lack of tree species, except for Nothofagus pumilio, and by the occurrence of understory species such as Gaultheria pumila (L.f.) D.J. Middleton and Schizeilema ranunculus Domin. Subgroup Ib is split, in its turn, in two subunits. Subunit Ib1 corresponds to a pure forest of Nothofagus pumilio which still hosts a significant floristic component of mixed forest in the low strata, while subunit $\mathrm{Ib} 2$ is composed by the samples from 500 and 550 masl consisting of low forests of Nothofagus pumilio at the higher altitude (krummholz, Fig. 2c) with abundant Gunnera magellanica Lam. and Senecio acanthifolius Hombr. \& Jacquinot ex Decne. in the herbaceous stratum.

Group II can also be split into two subunits according to Fig. 3. This division can be related to geomorphology and soil depletion in higher areas, where the instability of substrate becomes a new limiting factor for plant life. In these areas, clay and sandy soils give way to rocky substrates with steep slopes. Subgroup IIa consists of pulvinate-cushion plants on sandy areas which dominate relatively flat soils up to approx. 700 masl at Cerro Bandera. These formations are dominated by Bolax gummifera and
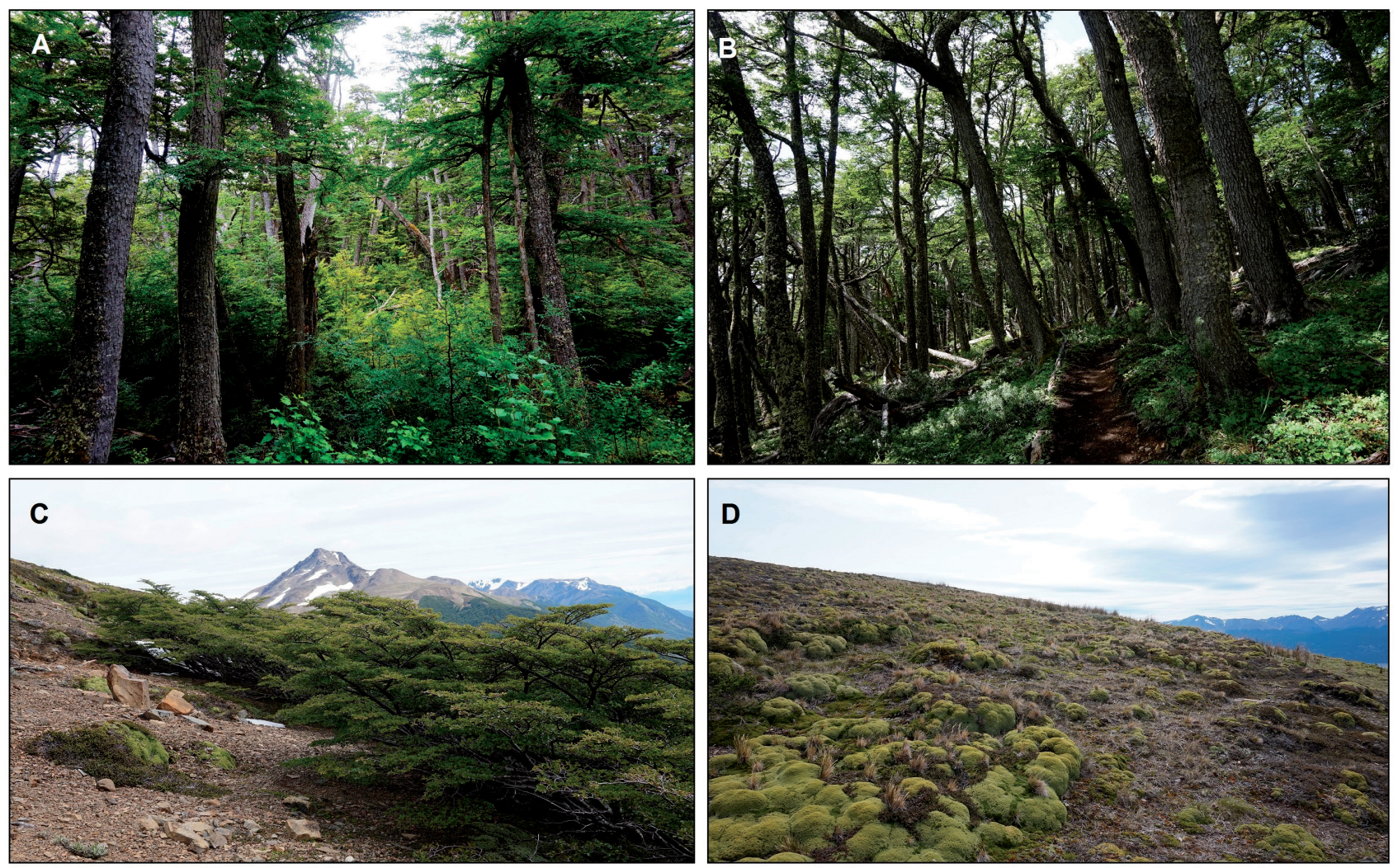

Figure 2. Plant-communities identified along the altitudinal gradient. (a) mixed forests of Nothofagus pumilio and Nothofagus betuloides, (b) pure forests of Nothofagus pumilio, (c) krummholz of Nothofagus pumilio, and (d) pulvinate cushions of Bolax gummifera and Abrotanella emarginata.

Figura 2. Comunidades vegetales identificadas a lo largo del gradiente altitudinal: (a) bosques mixtos de Nothofagus pumilio y Nothofagus betuloides, (b) bosques puros de Nothofagus pumilio, (c) krummholz de Nothofagus pumilio, y (d) matorrales en cojín de Bolax gummifera y Abrotanella emarginata. 
Acaena species in combination with dwarf shrubs (5-10 $\mathrm{cm}$ high) of Empetrum rubrum (Fig. 2D). Subgroup IIb consists of isolated plants growing in sheltered spots on steep slopes with rocky substrates. In this point, vascular plants are almost absent and other groups (lichens and bryophytes) become the dominating vegetation. This group is characterized by the presence of Polystichum andinum Phil., Nassauvia pygmaea (Cass.) Hook.f. and Gamochaeta nivalis Cabrera.

Vegetation CHANGES, BIOTEMPERATURES AND BIOCLIMATIC ZONES

The alpha diversity is higher for the forest than the tundra (Fig. 4, Table 1). The number of species in the forest increases slightly with elevation up to the low krummholz forest where it then decreases dramatically. Alpha diversity dropped steadily in the tundra transect obtaining the lowest value (14 species) at the highest altitudes (750 and 800 masl). The highest species turnover was obtained at the tree line (550 to 600 masl) where the forest gives way to cushion shrubs. Beta diversity also increases from 300 to
350 masl where the pure forest of Nothofagus pumilio has lost its lower-altitude element (Berberis ilicifolia, Ribes magellanicum Poir., Deschampsia antarctica É. Desv. and Galium fuegianum Hook.f.) and conversely gains a higheraltitude element in its distribution (Gaultheria pumila, Festuca magellanica Lam., Schizeilema ranunculus). The increase of beta diversity from 450 to 500 masl, where the pure tall forest of $N$. pumilio yields to the low forest (krummholz) is determined by a significant drop in species richness (17 species).

Significant changes in vegetation relate to biotemperatures of $4.3{ }^{\circ} \mathrm{C}$ (mixed to pure forests), $3.3{ }^{\circ} \mathrm{C}$ (forest to krummholz), and $2.9^{\circ} \mathrm{C}$ (krummholz to tundra) (Fig. 4 , Table 1). The first two values characterize the thresholds for the middle oroantiboreal to upper oroantiboreal region $\left(4.25^{\circ} \mathrm{C}\right)$ and the oroantiboreal to oroantartic region $(3.25$ ${ }^{\circ} \mathrm{C}$ ) according to the climatic-phytogeographical system of Tuhkanen (1992). These three bioclimatic zones (middle oroantiboreal, upper oroantiboreal, oroantartic belts) are comparable to the Mesoboreal, Supraboreal and Oroboreal typology of Rivas-Martínez (Rivas-Martínez et al. 1999).

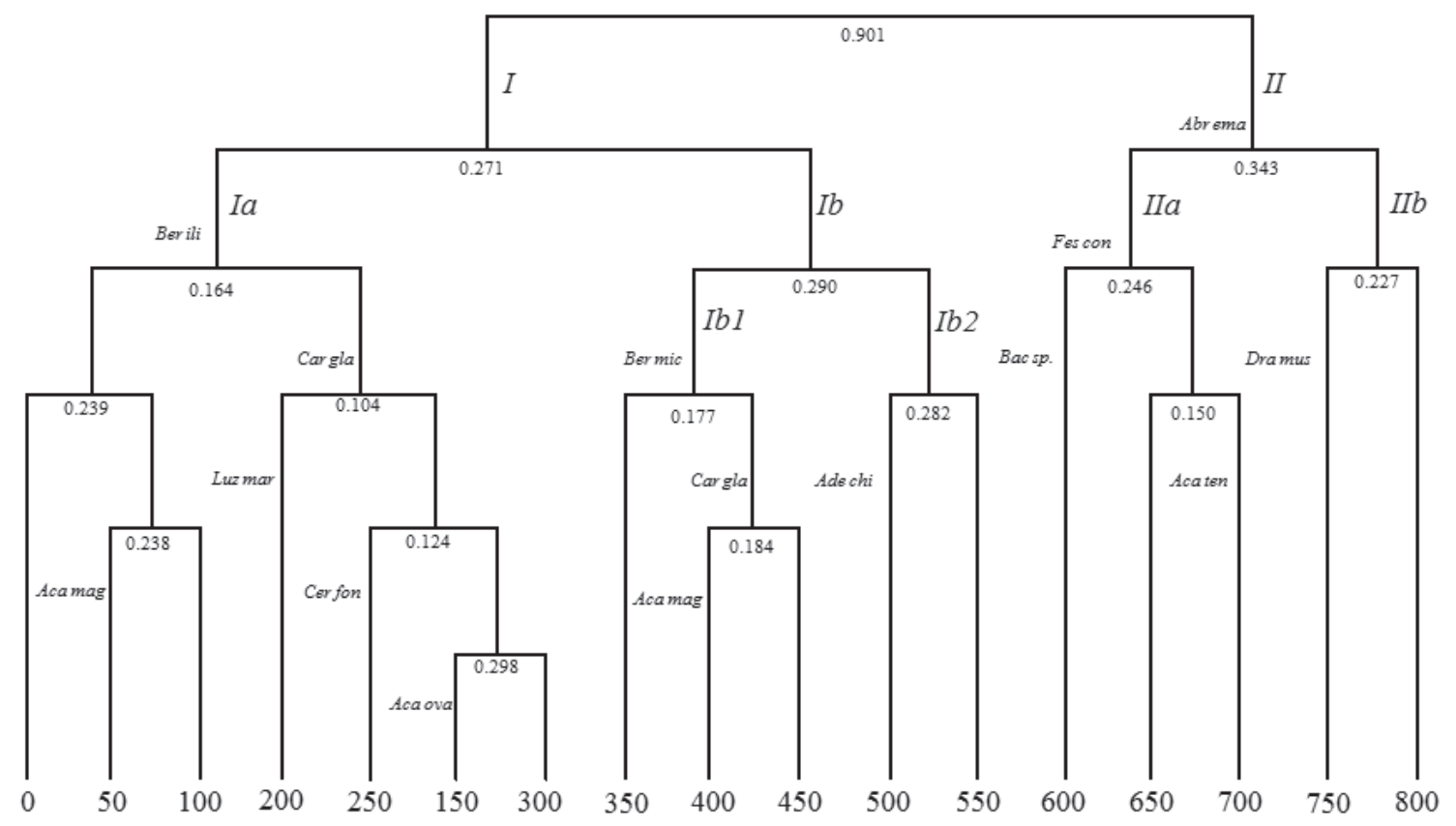

FIgURE 3. Dendrogram obtained from a Twinspan classification analysis on 17 vegetation samples from an altitudinal gradient at Cerro Bandera. Numbers bellow the dendrogram show the altitudinal level. Abr ema $=$ Abrotanella emarginata (Gaudich.) Cass., Aca mag $=$ Acaena magellanica (Lam.) Vahl, Aca ten = Acaena tenera Albov, Aca ova = Acaena ovalifolia Ruiz \& Pav., Ade chi = Adenocaulon chilense Less., Bac sp. = Baccharis sp., Ber mic = Berberis microphylla G.Forst., Ber ili = Berberis ilicifolia L.f., Car gla $=$ Cardamine glacialis (G.Forst.) DC., Cer fon = Cerastium fontanum Baumg., Dra mus = Drapetes muscosus Lam., Fes con = Festuca contracta Kirk, Luz mar = Luzuriaga marginata (Gaertn.) Benth. \& Hook.f.

FIgURA 3. Dendrograma obtenido del análisis de clasificación Twinspan a partir de 17 muestreos de vegetación a lo largo del gradiente altitudinal en el Cerro Bandera. Los números bajo el dendrograma muestran la altitud. Abr ema = Abrotanella emarginata (Gaudich.) Cass., Aca mag = Acaena magellanica $($ Lam.) Vahl, Aca ten = Acaena tenera Albov, Aca ova = Acaena ovalifolia Ruiz \& Pav., Ade chi = Adenocaulon chilense Less., Bac sp. = Baccharis sp., Ber mic = Berberis microphylla G.Forst., Ber ili = Berberis ilicifolia L.f., Car gla $=$ Cardamine glacialis (G.Forst.) DC., Cer fon = Cerastium fontanum Baumg., Dra mus = Drapetes muscosus Lam., Fes con $=$ Festuca contracta Kirk, Luz mar = Luzuriaga marginata $($ Gaertn.) Benth. \& Hook.f. 
Plant-communities as bioclimate indicators: MoLINA, J.A. ET AL.

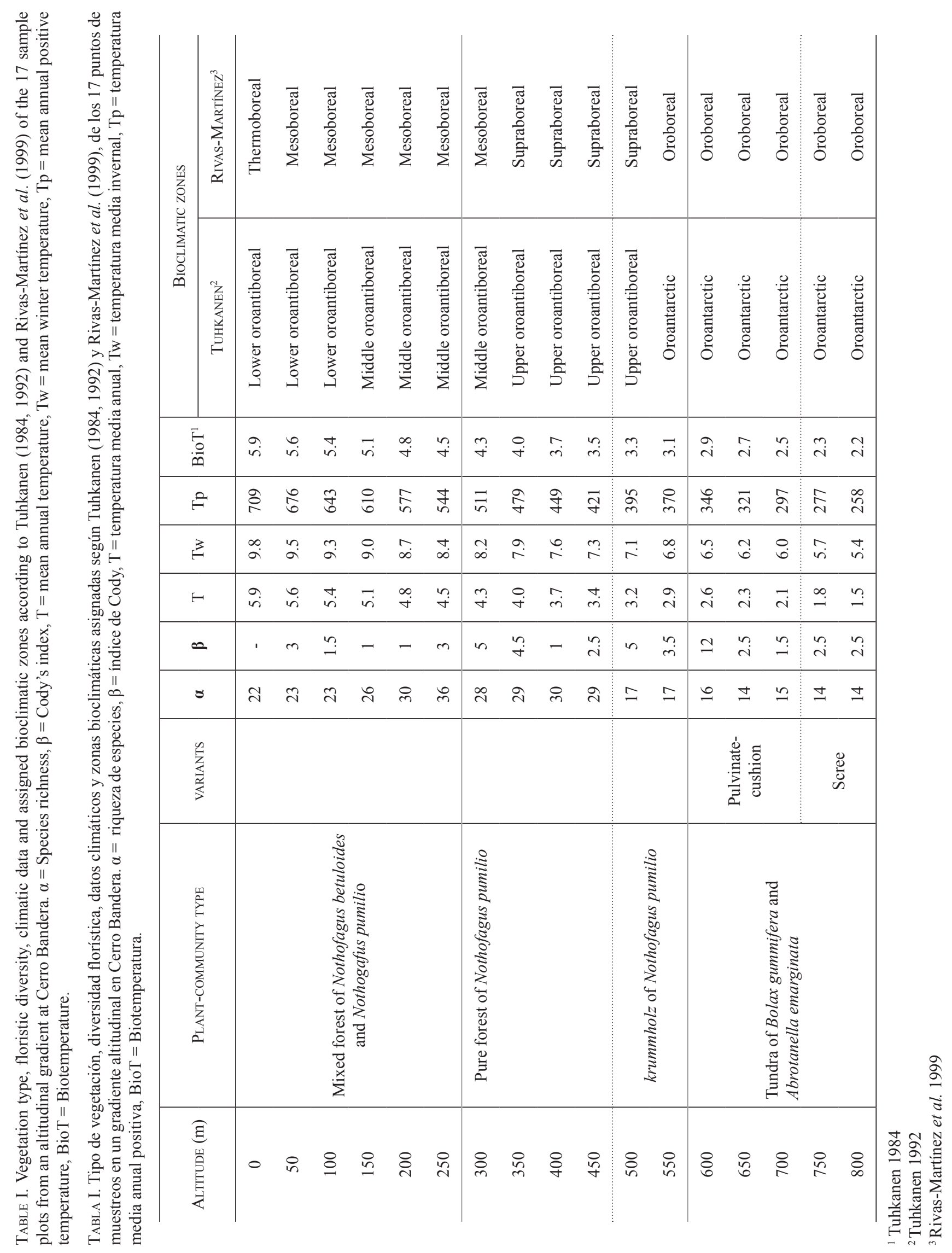




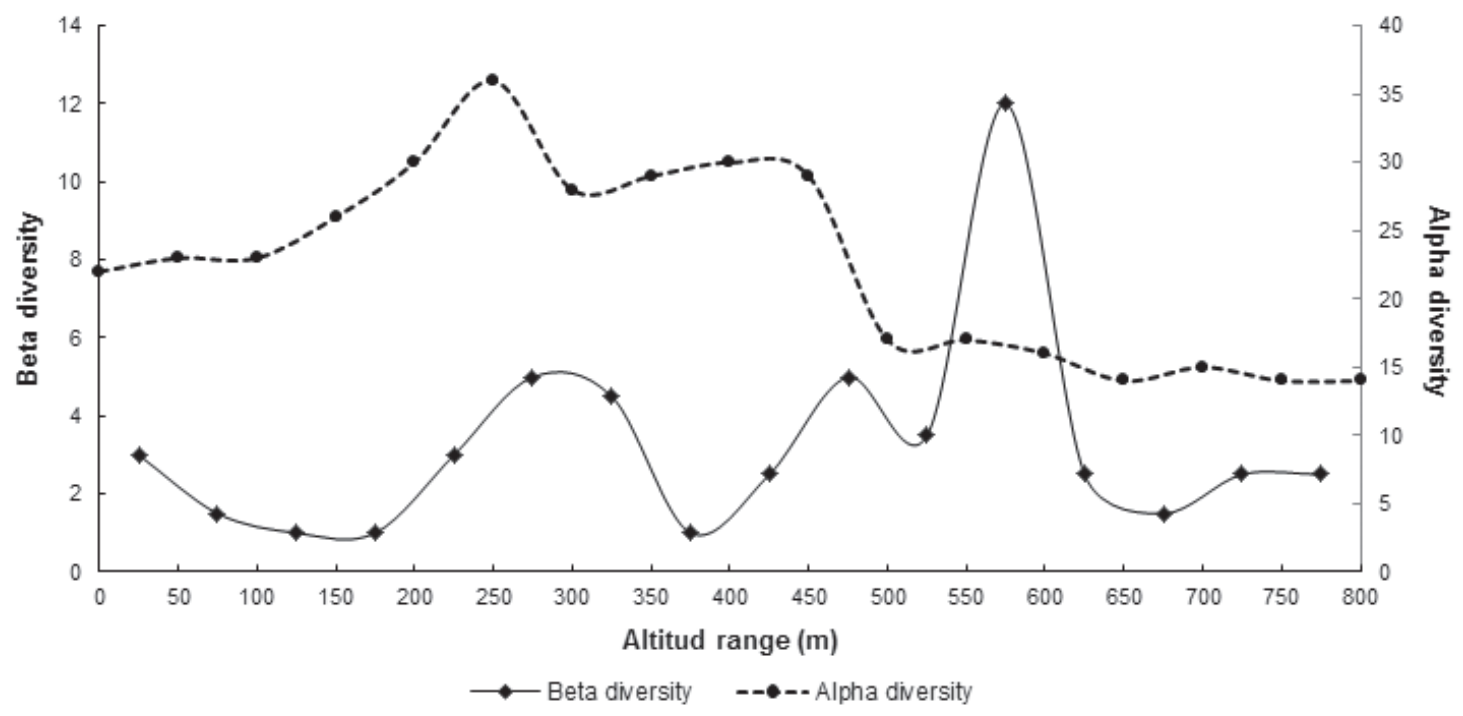

Figure 4. Alpha diversity (species richness) and Beta diversity (Cody's index). The graph shows the values obtained for both diversity parameters along the studied altitudinal levels.

Figura 4. Alfa diversidad (riqueza de especies) y beta diversidad (índice de Cody). El gráfico muestra los valores obtenidos para ambos estimadores de diversidad a lo largo del gradiente altitudinal estudiado.

\section{DISCUSSION}

According to this floristic survey, we identified the following four types of plant communities: mixed forest of Nothofagus betuloides-Nothofagus pumilio with Berberis ilicifolia and Drimys winteri; pure forest of Nothofagus pumilio with Gaultheria pumila and Festuca magellanica; krummholz of Nothofagus pumilio; and tundra characterised by Bolax gummifera and Abrotanella emarginata. Pure forests of $N$. betuloides, $N$. pumilio and $N$. antarctica as well as mixed forests of $N$. betuloides- $N$. pumilio and $N$. pumilio- $N$. antarctica have been described in Tierra del Fuego (Pisano 1977, Thiers \& Gerding 2007, Promis et al. 2008). In climatic transitional strips between hyperhumid and humid/ subhumid records of Magellanic areas, $N$. pumilio forests can co-exist with intrusions of $N$. betuloides (Amigo \& Rodríguez-Guitián 2011). This study shows that the tree Nothofagus pumilio has the widest elevational distribution, and is the only species capable of forming pure forests at higher altitudes on north central Isla Navarino. In contrast, $N$. betuloides occurs only as part of mixed forest with $N$. pumilio at lower altitudes. This pattern has already been described for the Subantarctic-Andean region (HildebrandVogel et al. 1990). But the results also reveal that the transition between these forests occurs throughout the ecotone of pure $N$. pumilio forest and sustains a significant lower-altitude element in the understory. It is important to note that $N$. pumilio is sensitive to drainage and rainfall, and it does not occur in the most western and southern areas of the CHBR, where forests are dominated by $N$. betuloides and the winter-deciduous $N$. antarctica (Rozzi et al. 2007). The two types of forest resulting from this study can be ascribed to the following forest types according to Luebert \& Pliscoff (2006): mixed temperate-antiboreal Andean forests of Nothofagus betuloides and Nothofagus pumilio and deciduous temperate-antiboreal Andean forests of Nothofagus pumilio and Maytenus disticha.

Vegetation near the timberline on Isla Navarino is strongly affected by exposure to wind, which creates a typical growth form -Fig. 2c- (Pollmann \& Hildebrand 2005). Nothofagus pumilio krummholz's understory is rich in certain herbs such as Senecio acanthifolius and Gunnera magellanica, which are reported to be characteristic of relatively wet and infertile soils (Kerr \& McAdam 2008). Nothofagus pumilio krummholz, however, has been defined as nutrient rich vegetation that acts as a nutrient sink with rapid turnover and accumulation of nutrients, which leads to both soil acidification and enrichment of certain nutrients such as C, N and P (Frangi et al. 2005).

The altitudinal transect used in this study reveals a typical pattern of an overall decreasing plant richness with increasing altitude, which was previously observed in southern Tierra del Fuego (Mark et al. 2001). However, this tendency seems not to be followed under the forest canopy. Alpha diversity increases slightly from 0 to 250 masl. This anomaly may be reflecting plant constriction by bagual herbivores (feral horses and cattle) and local cattle which graze freely in the lowlands of Cerro 
Bandera at least up to 150 masl (A Benavent-González, personal observation). Environmental conditions become more extreme along the altitudinal gradient, which is associated with decreasing temperature, soil development and nitrogen availability (Odland 2009). Only a few species are able to adapt to extreme conditions in the studied area, which explains why the decline in species richness is more pronounced in the tundra where typical pulvinate vegetation takes over (Pisano 1977, Odland 2009). Besides, cushion plants show a nurse effect by providing shelter from wind and increased soil moisture for plant recruitment (Cavieres et al. 2002, Callaway 2007, Méndez et al. 2013). It is important to note that our study focused on vascular plants; however, non-vascular plants (mosses and liverworts) have a greater diversity of species above the tree line, and their spatial distribution is less dependent on the presence of cushion plants (Méndez et al. 20013).

Also remarkable is the fact that some floristic differences were observed in the tundra belt. We did find that cover decreased at higher altitudes making the existing vegetation look more open. This transition matches with an increase of the slopes and the dominance of screes over 750 masl in Isla Navarino. The cushion-like vegetation gives way to more isolated plant forms which grow in sheltered spots between small ridges and stones. However, species composition does not clearly reflect this transition in terms of species richness or species turnover (Fig. 3). The abrupt topography of this area produces strong microclimatic differences among relatively close places, being this microclimatic influence stronger at higher parts of Cerro Bandera Hill (Méndez et al. 2013). Thus, the transition in the studied area from pulvinate-cushion forms to areas with isolated plants may be related to local geomorphology instead to the altitude effect on plant distribution.

The biotemperatures values to forest transitions obtained for this transect are close to the thresholds discriminating bioclimatic zones proposed by different authors (Table I). According to the results the krummholz band is located in the change between the upper oroantiboreal (or supraboreal) to oroantarctic (oroboreal) belts, and acts as a transitional band. These results support the bioindicator value of climax vegetation and allow us to locally define the following climactic plant-community types: lowermiddleoroantiboreal (or mesoboreal) mixed forest of Nothofagus betuloides-Nothofagus pumilio with Berberis ilicifolia and Drimys winteri; upper-oroantiboreal (or supraboreal) pure forest of Nothofagus pumilio with Gaultheria pumila and Festuca magellanica; oroantartic (or oroboreal) krummholz of Nothofagus pumilio; and oroantartic (or oroboreal) tundra characterised by Bolax gummifera and Abrotanella emarginata. Further research in other areas of Isla Navarino and adjacent territories is needed in order to obtain a robust regional model.

\section{ACKNOWLEDGEMENTS}

This work was supported by projects CTM200912838-C04-01/03 and CTM2012-38222-CO2-01 from Ministerio de Ciencia e Innovación (Spain). ABG benefits from a grant (BES-2013-062945) of the Ministerio de Economía y Competitividad of Spain. We are grateful to the Universidad de Magallanes (UMAG) and the Institute of Ecology and Biodiversity (grants MINECON ICM P05-002 and CONICYT PFB-23) for logistic and scientific support. We are indebted to Mercedes Vivas for her assistance in the field work. We would also like to thank Ms. Prudence Brooke-Turner for the English proofreading.

\section{REFERENCES}

Amigo, F.J. \& M.A. Rodríguez-Guitián. 2011. Bioclimatic and phytosociological diagnosis of the species of the Nothofagus genus (Nothofagaceae) in South America. International Journal of Geobotanical Research 1(1): 1-20.

Barrera, M.D., J.L. Frangi, L. Richter, M. Perdomo \& L. Pinedo. 2000. Structural and functional changes in Nothofagus pumilio forests along an altitudinal gradient in Tierra del Fuego, Argentina. Journal of Vegetation Science 11: 179188.

Braun-Blanquet, J. 1979. Fitosociología. Blume, Madrid. 820 pp.

Callaway, R.M. 2007. Positive interactions and interdependence in plant communities. Springer, Berlin. $415 \mathrm{pp}$.

CAmpoAmor, J.N. \& J.A. Molina. 2001. Diversity of Tricholomataceae along a Mediterranean altitudinal gradient. Cryptogamie Mycologie 22: 175-184.

Cavieres, L., M.T.K. Arroyo, A. Peñaloza, M. MolinaMontenegro \& C. Torres. 2002. Nurse effect of Bolax gummifera cushion plants in the alpine vegetation of the Chilean Patagonian Andes. Journal of Vegetation Science 13: 547-554.

Cuevas, J.G. 2000. Tree recruitment at the Nothofagus pumilio alpine timberline in Tierra del Fuego, Chile. Journal of Ecology 88: 840-855.

Donoso, C. 1995. Bosques templados de Chile y Argentina. Variación, estructura y dinámica. Tercera edición. Editorial Universitaria, Santiago de Chile. 485 pp.

Fajardo, A., F.I. Piper \& L.A. Cavieres. 2011. Distinguishing local from global climate influences in the variation of carbon status with altitude in a tree line species. Global Ecology and Biogeography 20: 307-318.

Font-Quer, P. 2001. Diccionario de Botánica. Ed. Península, Barcelona, $1280 \mathrm{pp}$.

Frangi, J. \& L.L. Richter. 1994. Balances hídricos de bosques de Nothofagus de Tierra del Fuego, Argentina. Revista de la Facultad de Agronomía, La Plata 70: 65-79.

Frangi, J.L., M.D. Barrera, L.L. Richter \& A.E. Lugo. 2005. Nutrient cycling in Nothofagus pumilio forests along an altitudinal gradient in Tierra del Fuego, Argentina. Forest Ecology and Management 217: 80-94.

Gerding, V. \& O. Thiers. 2002. Caracterización de suelos bajo bosques de Nothofagus betuloides (Mirb.) Blume, en 
Tierra del Fuego, Chile. Revista Chilena de Historia Natural 75: 819-833.

Gutiérrez, E., V.R. Vallejo, J. Romanya \& J. Fons. 1991. The subantarctic Nothofagus forests of Tierra del Fuego: distribution, structure and production. Oecologia Aquatica 10: 351-366.

Hildebrand-Vogel, R., R. Godoy \& A. Vogel. 1990. SubantarcticAndean Nothofagus pumilio forests. Vegetatio 89: 55-68.

HiLl, M.O. 1979. Twinspan - a fortran program for arranging multivariate data in an ordered two-way table by classification of the individuals and attributes. Cornell University, Ithaca, New York, 90 pp.

Hoffmann, J.A.J. 1975. Atlas climático de América del Sur. Mapas de temperatura y precipitaciones medias. WMO, UNESCO, Geneve, 4 pp +31 maps.

Holdridge, L.R. 1967. Life zone ecology. Tropical Science Center, San José. 206 pp.

Iturraspe, R., R. Sottini, C. Shroder \& J. Escobar. 1989. Generación de información hidroclimática en Tierra del Fuego. Hidrología y variables climáticas del territorio de Tierra del Fuego. CADIC, CONICET, Ushuaia. 170 pp.

JAX, K. 2010. Ecosystem functioning. Cambridge University Press, New York. 286 pp.

Kent, M. \& P. CoKer. 1992. Vegetation description and analysis. A practical approach. Belhaven, London. 363 pp.

KesLer, M. 2000. Elevational gradients in species richness and endemism of selected plant groups in the central Bolivian Andes. Plant Ecology 149: 181-193.

KerR, J.A. \& J.H. McAdAM. 2008. Characteristics of patches of short grasses and herbs in the Falkland Islands and their management for sheep grazing. Anales del Instituto de la Patagonia 36: 5-24.

Lara, A., R. Villalba, A. Wolodarsky-Franke, J.C. Aravena, B.H. Luckman \& E. CuQ. 2005. Spatial and temporal variation in Nothofagus pumilio growth at tree line along its latitudinal range $\left(35^{\circ} 40^{\prime}-55^{\circ} \mathrm{S}\right)$ in the Chilean Andes. Journal of Biogeography 32: 879-893.

Legendre, P. \& H.J. Birks. 2012. Clustering and Partioning. In: H.J. Birks, A.F. Lotter, S. Juggings \& J.P. Smol (eds.), Tracking environmental change using lake sediments, vol. 5, pp 167-200. Springer, Dordrecht, Netherlands.

Luebert, F. \& P. Pliscoff. 2006. Sinopsis bioclimatica y vegetacional de Chile. Edit. Universitaria, Santiago de Chile. 316 pp.

MagurRan, A.E. 1988. Ecological diversity and its measurement. Chapman \& Hall, Bangor. 179 pp.

Mark, A.F., K.J.M. Dickinson, J. Allen, R. Smith \& C.J. West. 2001. Vegetation patterns, plant distribution and life forms across the alpine zone in southern Tierra del Fuego, Argentina. Austral Ecology 26: 423-440.

Méndez, M., R. Rozzi \& L. Cavieres. 2013. Flora vascular y musgos en la zona altoandina de la Isla Navarino $\left(55^{\circ} \mathrm{S}\right)$, Reserva de la Biosfera Cabo de Hornos, Chile. Gayana Botánica 70: 337-343.

Menichetti, M., E. Lodolo \& A. TAssone. 2008. Structural geology of the Fuegian Andes and Magallanes fold-and-thrust belt Tierra del Fuego Island. Geologica Acta 6: 19-42.

Mittermeier, R.A., C.G. Mittermeier, P. Robles-Gil, J.D. Pilgrim, G.A.B. Da Fonseca, T.M. Brook \& W.R. Konstant. 2003. Wilderness: Earth's Last Wild Places. CEMEX-
Conservation International, Washington DC. 576 pp.

Moore, D.M. 1983. Flora of Tierra del Fuego. Anthony Nelson, Shropshire, England and Missouri Botanical Garden, St. Louis. 396 pp.

OdLAND, A. 2009. Interpretation of altitudinal gradients in South Central Norway based on vascular plants as environmental indicators. Ecological Indicators 9: 409-421.

Olivero, E.B. \& D.R. Martinioni. 2001. A review of the geology of the Argentinian Fueguian Andes. Journal of South American Earth Sciences 14: 175-188.

Pisano, E. 1977. Fitogeografía de Fuego-Patagonia Chilena. I-Comunidades vegetales entre las latitudes $52^{\circ}$ y $56^{\circ}$. Anales del Instituto de la Patagonia 8: 121-250.

Pisano, E. 1981. Bosquejo fitogeográfico de fuego-patagonia. Anales del Instituto de la Patagonia 12: 159-171.

Pisano, E. 1983. The Magellanic tundra complex. In: A.J.P. Gore (ed.), Mires: swamp, bog, fen and moor. Ecosystems of the world. Vol. 4B, pp 295-329. Elsevier, Amsterdam, Netherlands.

Pollmann, W. \& R. Hildebrand. 2005. Structure and the composition of species in timberline ecotones of the southern Andes: In: G. Broll \& B. Keplin (eds.), Mountain ecosystems: studies in treeline ecology, pp. 117-152. Publisher Springer, Berlin, Germany.

Promis, A., G. Cruz, A. Reif \& S. Gärtner. 2008. Nothofagus betuloides (Mirb.) Oerst. 1871 (Fagales: Nothofagaceae) forests in southern Patagonia and Tierra del Fuego. Anales del Instituto de la Patagonia 36: 53-67.

Rivas-Martínez, S. \& S. Rivas-SÁenz (1996-2009). Sistema de Clasificación Bioclimática Mundial Centro de Investigaciones Fitosociológicas, España. http://www. ucm.es/info/cif/station/ch-navar.htm (accessed June 2010).

Rivas-Martínez, S., D. SÁnchez-Mata \& M. Costa. 1999. North American Boreal and Western Temperate Forest Vegetation. Itinera Geobotanica 12: 5-316.

Rozzi, R., F. Massardo, C.B. Anderson, K. Heidinger \& J.A. Silander. 2006a. Ten principles for biocultural conservation at the southern tip of the Americas: the approach of the Omora Ethnobotanical Park. Ecology and Society 11: 43-70.

Rozzi, R., F. Massardo, C.B. Anderson, A. Berghoefer, A. Mansilla, M. Mansilla \& J. Plana. 2006b. Reserva de Biosfera Cabo de Hornos. Ediciones de la Universidad de Magallanes, Punta Arenas. 258 pp.

Rozzi, R., F. Massardo, A. Mansilla, C. Anderson, A. Berghöfer, M. Mansilla, M.R. Gallardo, J. Plana, U. Berghöfer, X. Arango, S. Russell, P. Araya \& E. Barros. 2007. La Reserva de Biosfera Cabo de Hornos: un desafío para la conservación de la biodiversidad e implementación del desarrollo sustentable en el extremo austral de América. Anales del Instituto de la Patagonia 35: 55-62.

Rozzi, R., J.J. Armesto, B. Goffinet, W. Buck, F. Massardo, J. Silander, M. Arroyo, S. Russell, C. Anderson, L. Cavieres \& J. Callicott. 2008. Changing lenses to assess biodiversity: patterns of species richness in sub-Antarctic plants and implications for global conservation. Frontiers in Ecology and the Environment 6: 131-137.

Rozzi, R., J.J. Armesto, J. Gutiérrez, F. Massardo, G. Likens, C. Anderson, A Poole, K. Moses, G. Hargrove, A. Mansilla, J.H. Kennedy, M. Willson, K. JaX, C. Jones, J.B. 
Callicott \& M.T. Kalin. 2012. Integrating ecology and environmental ethics: Earth stewardship in the southern end of the Americas. BioScience 62: 226-236.

Sanderson, E., M. Jaith, M. Levy, K. Redford, A. Wannebo \& G. Woolmer. 2002. The human footprint and the last of the wild. BioScience 10: 891-904.

Santana, A., C. Porter, N. Butorovic \& C. Olave. 2006. Primeros antecedentes climatológicos de estaciones automáticas (AWS) en el canal Beagle, Magallanes, Chile. Anales del Instituto de la Patagonia 34: 5-20.

SIEG, B. \& F.J.A. DANIËLS. 2005. Altitudinal zonation of vegetation in continental West Greenland with special reference to snowbeds. Phytocoenologia 35: 887h-908.

Thiers, O. \& V. Gerding. 2007. Variabilidad topográfica y edáfica en bosques de Nothofagus betuloides (Mirb.) Blume, en el suroeste de Tierra del Fuego. Chile. Revista Chilena Historia Natural 80: 201-211.

TuHKANEN, S. 1984. A circumboreal system of climatic- phytogeographical regions. Acta Botanica Fennica 107: $1-50$.

TuhKanen, S. 1992. The climate of Tierra del Fuego from a vegetation geographical point of view and its ecoclimatic counterparts elsewhere. Acta Botanica Fennica 145: 1-64.

Veblen, T.T., C. Donoso, T. Kitzberger \& A.J. Rebertus. 1996. Ecology of southern Chilean and Argentinean Nothofagus forests. In: T.T. Veblen, R.S. Hill \& J. Read (eds.), The ecology and biogeography of Nothofagus forests, pp. 293353. Yale University Press, New Haven, USA.

WebB, P.N. \& D.M. Harwood. 1993. Pliocene fossil Nothofagus (southern beech) from Antarctica: phytogeography, dispersal strategies, and survival in high latitude glacialdeglacial environments. In: J. Alden, J.L. Mastrantonio \& S. Odum (eds.), Forest development in cold climates. pp. 135-165. Plenum Press, New York,

Zonneveld, S. 1983. Principles of bio-indication. Environmental Monitoring and Assessment 3: 207-217.

Recibido: 29.09 .15

Aceptado: 29.09.16 